\title{
Geotechnical stability assessment of a railway arch bridge more than 100-year old: a case study
}

\author{
PRIYANKA GHOSH ${ }^{1, *}$, RAJEEV SHRIVASTAVA $^{2}$ and ABHIJEET SWAIN ${ }^{1}$ \\ ${ }^{1}$ Department of Civil Engineering, Indian Institute of Technology Kanpur, Kanpur 208 016, India \\ ${ }^{2}$ West North Central Railway, Allahabad, India \\ e-mail: priyog@iitk.ac.in
}

MS received 25 October 2018; revised 28 May 2019; accepted 16 June 2019

\begin{abstract}
In the present investigation, the geotechnical stability of the substructure of 100-year-old brick masonry rail bridges has been analysed numerically in the presence of nearby newly proposed concrete box bridges. Two different arch bridges (1273/1 and 1274/1) of Indian Railways (IR) have been considered in this analysis. Both bridges are made of brick masonry with different numbers of barrels. The numerical analysis has been performed using the finite-element (FE) method. The existing railway track between Kanpur and Jhansi, India, runs on these bridges, which were basically constructed by the British between 1888 and 1900. Therefore, the assessment of geotechnical safety and stability of such heritage bridges was of paramount importance from the IR point of view since the modern rail loading and other associated factors were changed significantly. A detailed geotechnical investigation along with the plate load test was carried out at the respective bridge locations, and the results are reported in this paper. The distribution of the vertical stress and the settlement developed below the foundation of the bridges have been acquired from the FE investigation to judge the foundation safety against the strength and the serviceability perspective.
\end{abstract}

Keywords. Bearing capacity; foundation interaction; geotechnical investigation; railway arch bridge; settlement.

\section{Introduction}

The railway is considered to be one of the major transportation facilities in several countries and India is not an exception. The Indian Railways (IR) is one of the oldest railway organizations over the globe, which was initiated by the British in 1853 . In India, the railways provide the least expensive and most advantageous method of passenger transport both for long distance and suburban traffic. It has played a significant role in the development and the growth of the country by evacuating separation amongst the urban areas and the countryside, and has assumed a noteworthy part in spreading developments and new thoughts. The IR has advanced a great deal, both qualitatively and quantitatively, during the last few decades. To continue with the growth, the IR recently decided to lay down $204 \mathrm{~km}$ long second railway track next to the current track between Bhimsen Junction $\left(26.4195^{\circ} \mathrm{N}, 80.2177^{\circ} \mathrm{E}\right)$ near Kanpur Central $\left(26.4539^{\circ} \mathrm{N}, 80.3512^{\circ} \mathrm{E}\right)$ and Jhansi Junction $\left(25.4452^{\circ} \mathrm{N}, 78.5527^{\circ} \mathrm{E}\right)$ railway stations (figure 1). Kanpur Central is one of the five "Central" railway stations in India, which is the busiest railway station in the state Uttar Pradesh in terms of the frequency of trains. Kanpur

*For correspondence

Published online: 03 August 2019
Central is a major intercity rail and commuter rail station in the city of Kanpur and is located on the Howrah-Delhi broad gauge route passing through Uttar Pradesh. Being the busiest station of the North Central Railways, Kanpur Central accommodates around 372 trains and traffic of more than 7,50,000 passengers daily, while Jhansi Junction is a major railway junction in the city of Jhansi in Bundelkhand region of Uttar Pradesh, which is one of the busiest and largest railway stations in India. Jhansi Junction is a significant intercity hub and a technical stoppage for many superfast trains in India, which lies on the main Delhi-Chennai and Delhi-Mumbai rail route. Being an old rail network in the world, the IR apparently owns several old heritage structures such as bridges and buildings. Therefore, it has been a significant challenge for the IR to maintain the well-being of such heritage structures while accommodating the modernization. The existing track between Kanpur Central and Jhansi Junction is such an old route, which was laid down by the British between 1888 and 1900. Due to the topography, the existing track (figure 1) keeps running over several brick masonry arch bridges, which were constructed by the British more than 100 years ago. Thereafter the loading applied on the railway tracks has been changed to a great extent due to the modernization of the railway facilities. With the 


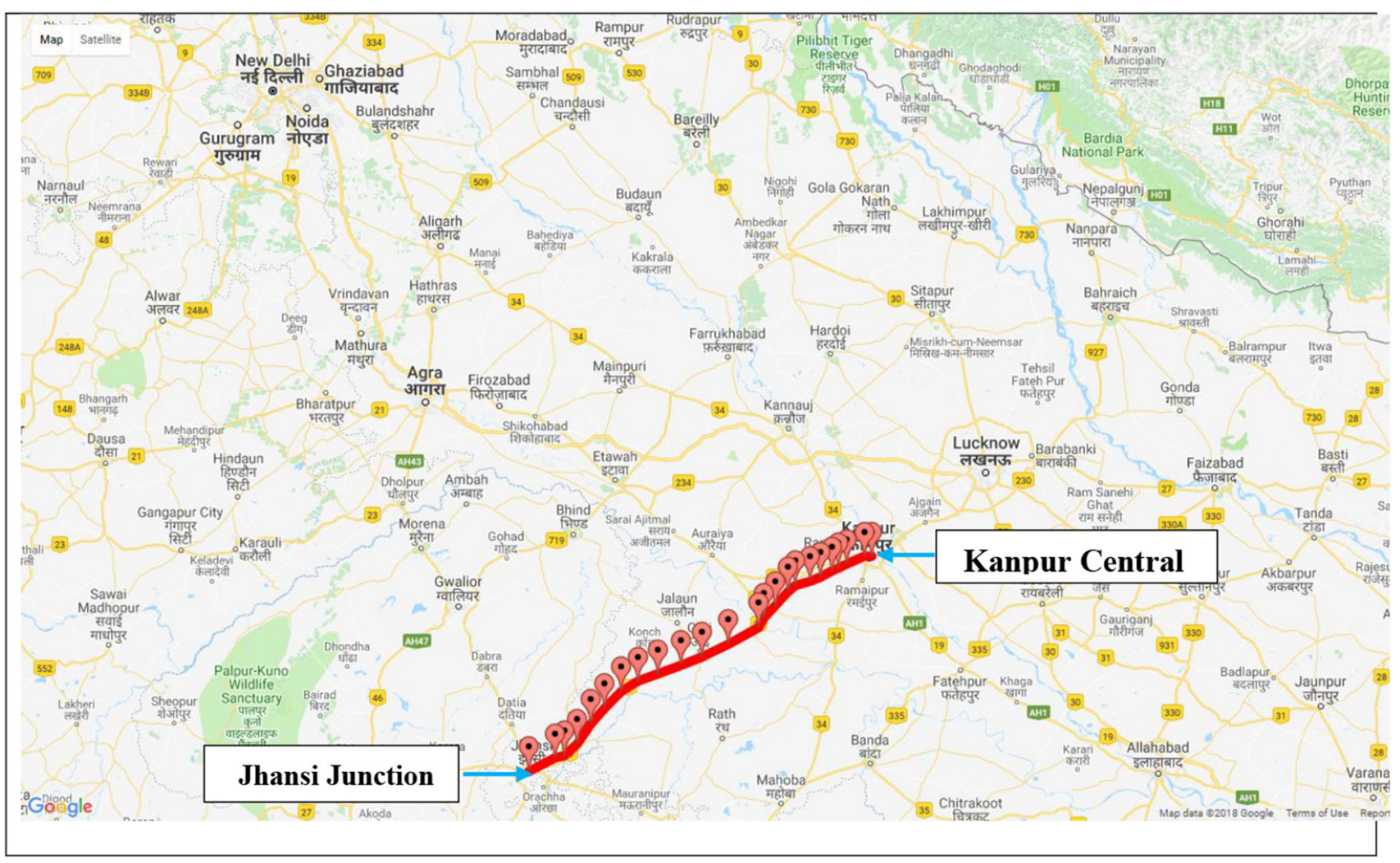

Figure 1. Existing railway track between Kanpur Central and Jhansi Junction (source: http://www.onefivenine.com/india/Rail/ RailDetails/54158).

enhancement in the rail loading, only the visual distress of such old railway bridges used to be monitored by the IR to identify the requirement of any rehabilitation process such as the generic reinforced cement concrete (RCC) jacketing of the bridges. With the proposed doubling of the railway track between Bhimsen Junction and Jhansi Junction, the new track is planned to keep running over the concrete box bridges constructed adjacent to the existing old bridges. Hence, a need was felt to investigate the geotechnical safety and stability of the substructure of the existing old heritage bridges due to the construction of the adjacent newly proposed concrete box bridges [1]. Besides, the IR also planned to enhance the applied live load (train load) on the existing as well as the proposed tracks. Therefore, a significant amount of interaction was expected to happen between the foundations of the old and the new bridges. The interaction effect of closely spaced foundations has been studied by several researchers [2-14], where it has been demonstrated that the bearing capacity of the interacting foundations generally gets enhanced at the cost of a higher settlement. Therefore, in the present study, the geotechnical stability of the existing old bridges in terms of the vertical stress and the settlement developed below the foundation has been explored in the presence of the newly proposed bridges. For the sake of brevity, out of several such old arch bridges, only two bridges (1273/1 and
1274/1) have been considered in this paper. Bridge 1273/1 is made of brick masonry with three barrels as shown in figure 2a, whereas bridge $1274 / 1$ is made of brick masonry with two barrels as shown in figure $2 b$. It can be seen from figure 2 that both bridges carry a significant height of an earth cushion on the top of the superstructure. In this study, the vertical stress and the settlement developed at the base of the existing bridge in the presence of the proposed bridge have been determined using the finite-element (FE) analysis [15]. The present investigation is purely based on a case study that has assessed the geotechnical stability of railway bridges in India more than 100 years old under the enhanced rail loading and the changed site conditions.

\section{Geotechnical investigation and plate load test}

Geotechnical investigations were carried out at the respective bridge locations, which included the scope of detailed subsoil investigation and the plate load test. The subsoil investigation included field exploration, in-situ testing and collection of the soil samples, laboratory testing and analysis of the test results. A borehole $150 \mathrm{~mm}$ in diameter and $15 \mathrm{~m}$ in depth was drilled at each bridge location. For the advancement of the boreholes at the selected locations, the percussion drilling technique was 

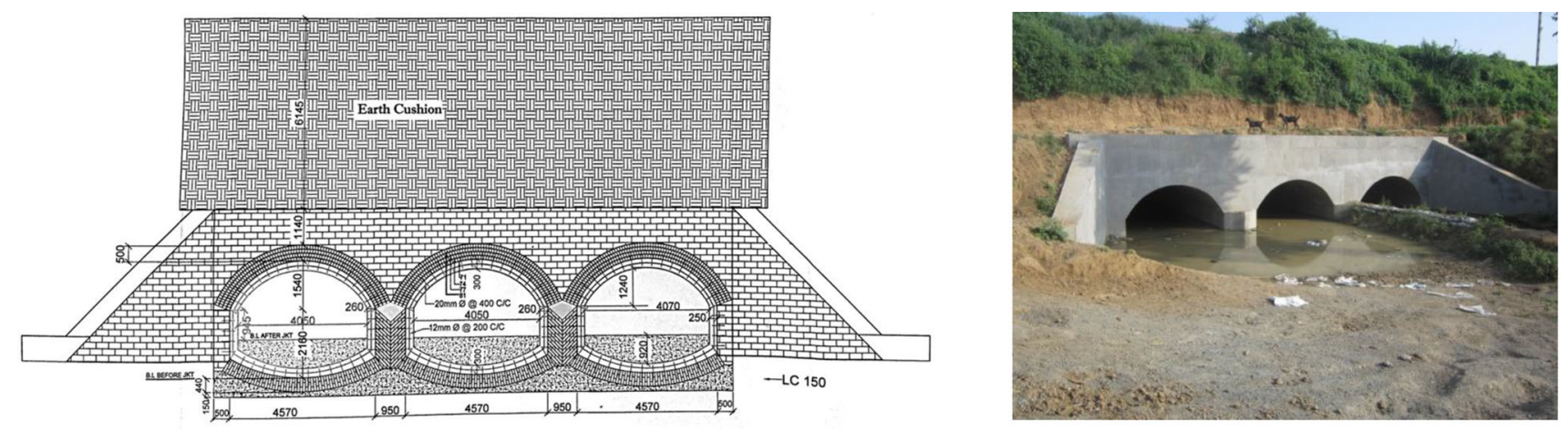

(a)
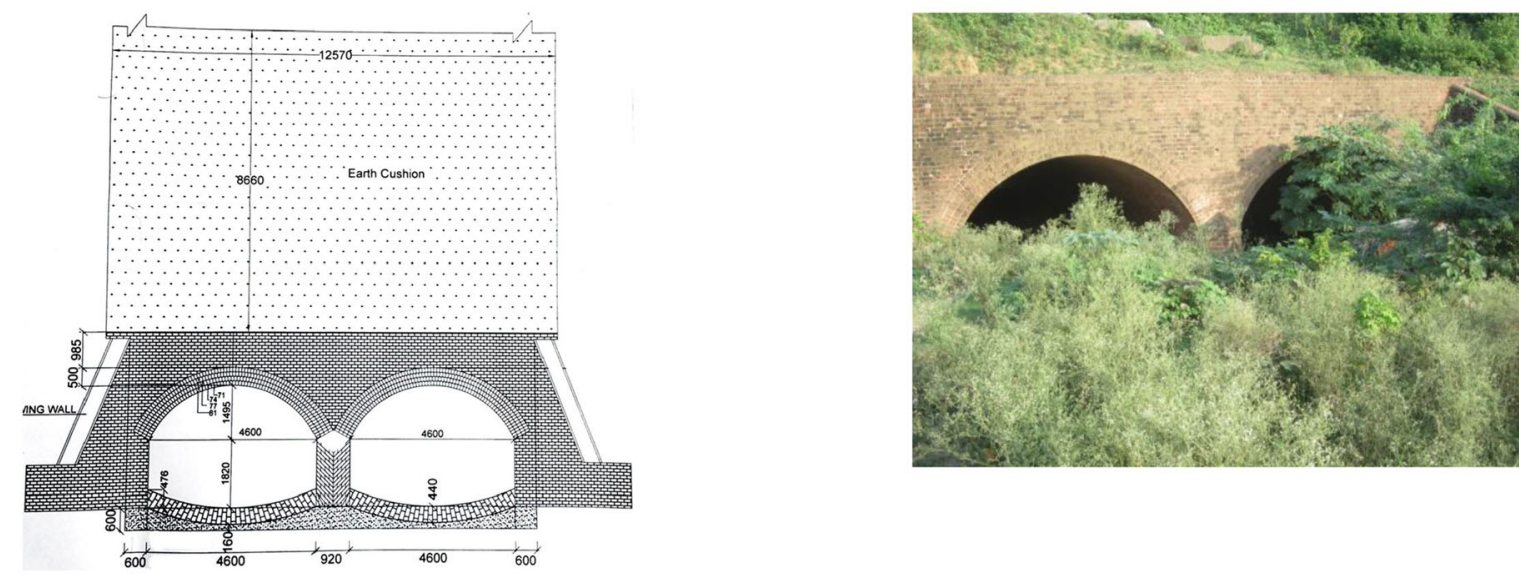

(b)

Figure 2. Sectional elevation details of the existing bridge: (a) 1273/1 and (b) 1274/1 (all dimensions are in mm) (modified after RVNL).

adopted. Disturbed and undisturbed soil samples representing various subsoil layers encountered were collected. The disturbed soil samples were used for the identification and the classification purpose, whereas the undisturbed samples were used for the evaluation of the strength and the compressibility properties of the soil. With the advancement of the boreholes, standard penetration tests (SPT) were performed at regular intervals in each of the boreholes as per the procedure stipulated in the Indian standard specification [16], and eventually, the $N$ values were recorded at each stage. Soil samples collected from the field were brought to conduct various laboratory tests to determine different soil parameters [17]. For different bridge locations, the bore-log data and the classification of soil as per the IS classification system at different depths are given in figure 3. From the bore-log data presented in figure $3 \mathrm{a}$, the subsurface soil layers at the location of bridge 1273/1 are generally found to be medium plastic silty clay (CL-CI) or low to medium silt (ML-MI) depending upon the presence of the silt content throughout the explored depth of $15.75 \mathrm{~m}$. The $N$ values observed at the location varied from 22 (at $3.30 \mathrm{~m}$ depth) to 38 (at $15.30 \mathrm{~m}$ depth). Similarly, from figure $3 b$, it can be seen that the subsurface soil at the location of bridge 1274/1 predominantly consists of clay with medium compressibility (CI) and to some extent contains clay with low compressibility (CL) and intermediate silt (ML). The $N$ values observed at the site varied from 14 (at $1.80 \mathrm{~m}$ depth) to 38 (at $15.30 \mathrm{~m} \mathrm{depth).} \mathrm{The}$ groundwater table was not encountered in any of the bridge locations during the field exploration. Figures 4 and 5 show the typical gradation curves for the soil collected from various depths of the boreholes at different bridge sites. The $p-q$ plots were established by performing UU triaxial tests on the undisturbed soil samples collected from multiple depths of the boreholes and the undrained shear strength parameters $\left(c_{\mathrm{u}}\right.$ and $\left.\phi_{\mathrm{u}}\right)$ determined from the respective $p$ $q$ plots are reported in figure 3 .

At both of the bridge locations, plate load test was performed as per the procedure laid down in the Indian standard specification [18]. From the pressure-settlement curve obtained from the plate load test conducted at the location of bridge 1273/1 (figure 6a), it can be observed that the curve follows a conventional and steady-state increasing trend when the pressure on the test plate reaches up to $70.77 \mathrm{t} / \mathrm{m}^{2}(694.02 \mathrm{kPa})$ with a total settlement of $14.54 \mathrm{~mm}$. Adopting the double tangent method, the 


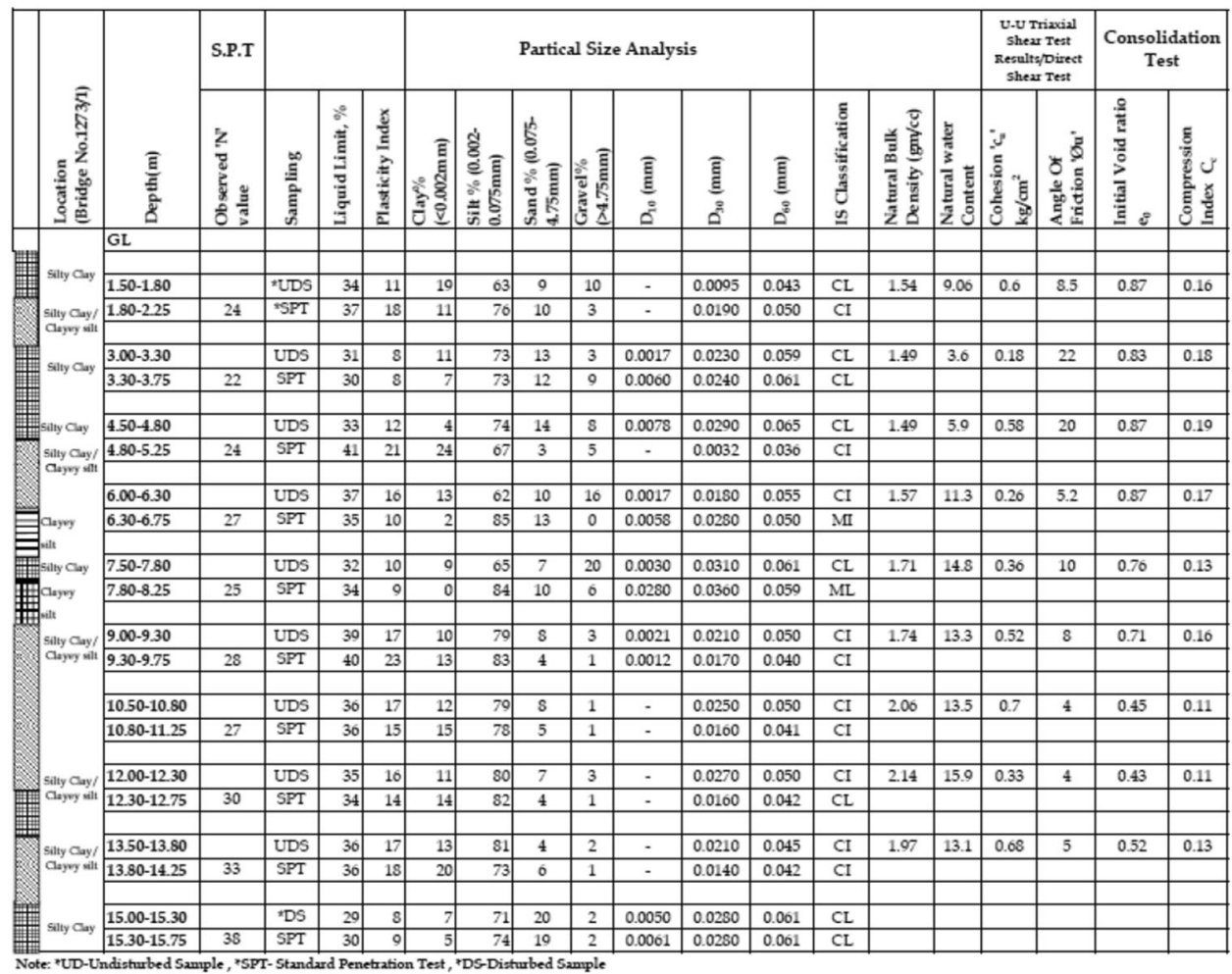

(a)

\begin{tabular}{|c|c|c|c|c|c|c|c|c|c|c|c|c|c|c|c|c|c|c|c|}
\hline \multirow[b]{2}{*}{ 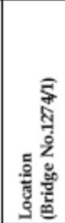 } & \multirow[b]{2}{*}{ 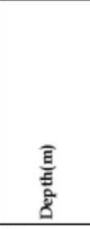 } & \multirow{2}{*}{ 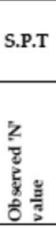 } & \multirow[b]{2}{*}{ 营 } & \multirow[b]{2}{*}{ 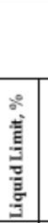 } & \multirow[b]{2}{*}{ 旅 } & \multicolumn{7}{|c|}{ Partical Size Analysis } & \multirow[b]{2}{*}{ 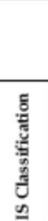 } & \multirow[b]{2}{*}{ 窇产 } & \multirow[b]{2}{*}{ 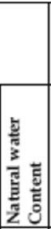 } & \multicolumn{2}{|c|}{$\begin{array}{c}\text { U.U Triavial } \\
\text { She ir Teat } \\
\text { Resultspirect } \\
\text { She ix Test }\end{array}$} & \multicolumn{2}{|c|}{$\begin{array}{c}\text { Consolidation } \\
\text { Test }\end{array}$} \\
\hline & & & & & & 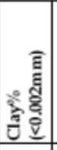 & 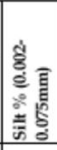 & 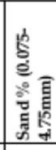 & 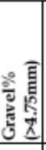 & $\begin{array}{l}\bar{E} \\
\frac{E}{5} \\
\end{array}$ & $\begin{array}{l}\overline{\mathrm{E}} \\
\mathrm{s} \\
\end{array}$ & $\frac{\overline{1}}{8}$ & & & & 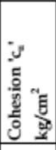 & 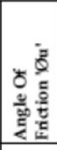 & 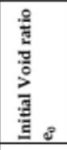 & 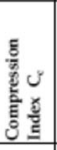 \\
\hline & GL & & & & & & & & & & & & & & & & & & \\
\hline & $1.50-1.80$ & & *UDS & 36 & 17 & 11 & 51 & 32 & 6 & 0.0015 & 0.032 & 0.07 & $\mathrm{CI}$ & 1.8 & 7.3 & 0.74 & 11 & 0.57 & 0.05 \\
\hline & $1.80-2.25$ & 14 & SPPT & 31 & 14 & 15 & 45 & 30 & 7 & - & 0.019 & 0.068 & $\mathrm{CL}$ & & & & & & \\
\hline & $3,30 .-30$ & & UDS & 34 & 10 & 2 & 50 & 0 & 8 & 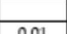 & & & & (1) & 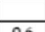 & 0 & 72 & & 85 \\
\hline & $3.00-3.75$ & 16 & SPT & 35 & 17 & 20 & 73 & $\frac{9}{7}$ & $\frac{0}{1}$ & $\frac{0.1}{-}$ & 0.0095 & $\begin{array}{ll}0.001 \\
0.041\end{array}$ & $\mathrm{CI}$ & 1.03 & & 0.49 & & & \\
\hline & & & & & & & & & & & & & & & & & & & \\
\hline & $4.50-4.80$ & & ${ }^{\circ} \mathrm{DS}$ & 39 & 15 & 24 & 70 & 6 & 0 & - & 0.0045 & 0.038 & $\mathrm{CI}$ & 1.97 & 18.6 & \begin{tabular}{|l|}
0.22 \\
\end{tabular} & 0 & 0.56 & \\
\hline Gyyey at & $4.80-5.25$ & 17 & SPT & 34 & 9 & 4 & 90 & 6 & 0 & - & 0.025 & 0.048 & ML & & & & & & \\
\hline & $6.00-6.30$ & & DS & 37 & 10 & 15 & 75 & 9 & 1 & - & 0.010 & 0.041 & $\mathrm{CI}$ & 1.91 & 16.2 & 1.84 & 5.4 & 0.6 & 0.14 \\
\hline & $6.30-6.75$ & 27 & SPT & 35 & 15 & 18 & 69 & 9 & 4 & - & 0.0096 & 0.04 & $\mathrm{CI}$ & & & & & & \\
\hline & $7.50-7.80$ & & DS & 35 & 16 & 26 & 63 & 10 & 1 & - & 0.0042 & 0.036 & CI & 2.07 & 17.3 & 0 & 22 & 0.49 & 0.12 \\
\hline & $7.80-8.25$ & 32 & SPT & 32 & 12 & 11 & 80 & 7 & 1 & 0.0017 & 0.017 & 0.041 & $\mathrm{CL}$ & & & & & & \\
\hline & $90-930$ & 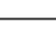 & $D S$ & 南 & t & to & & 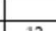 & 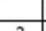 & & & & & $m$ & & 0 & & 05 & \\
\hline 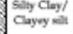 & $9.30-9.75$ & 20 & SPT & 36 & $\frac{217}{17}$ & $\frac{10}{15}$ & $\frac{1}{72}$ & $\frac{12}{11}$ & $\frac{2}{2}$ & 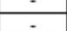 & 0.016 & 0.05 & CI & 1.99 & 17 & & & 0.51 & 0.13 \\
\hline & & & & & & & & & & & & & & & & & & & \\
\hline & $10.50-10.80$ & & DS & 36 & 18 & 12 & 62 & 17 & 9 & 0.0019 & 0.011 & 0.06 & CI & & & & & & \\
\hline Conyy at & $10.80-11.25$ & 29 & SFT & 38 & 19 & 16 & 58 & 17 & 9 & - & 0.0089 & 0.039 & $\mathrm{CI}$ & & & & & & \\
\hline & & & $\pi 9$ & & & t & & & 7 & & 0015 & 805 & & 203 & $17-7$ & 003 & 1 & & \\
\hline 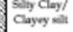 & $\frac{120.30-12.50}{1230-75}$ & 36 & SPT & 38 & $\frac{19}{18}$ & $\frac{11}{13}$ & $\frac{65}{65}$ & $\frac{10}{15}$ & 7 & 0.0015 & \begin{tabular}{|l|}
0.013 \\
0.013 \\
\end{tabular} & 0.055 & $\mathrm{CI}$ & 2.00 & 10.7 & 0.09 & 10 & 0.34 & 0.12 \\
\hline & & & & & & & & & & & & & & & & & & & \\
\hline saby cary/ & 13.50-13.80 & & DS & 38 & 20 & 16 & 63 & 15 & 6 & - & $\begin{array}{ll}0.013 \\
\end{array}$ & 0.045 & $\mathrm{CI}$ & 1.97 & 18.7 & \begin{tabular}{|l|}
0.32 \\
\end{tabular} & 10 & 0.58 & 0.12 \\
\hline canyy at & $13.80-14.25$ & 37 & SPT & 39 & 18 & 17 & 72 & 9 & 2 & - & 0.0055 & \begin{tabular}{l|l|}
0.018 \\
\end{tabular} & $\mathrm{CI}$ & & & & & & \\
\hline & & & & & & & & & & & & & & & & & & & \\
\hline 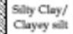 & $\frac{15.00-15.30}{15.30-157}$ & 38 & $\begin{array}{l}\text { DSS } \\
\text { SPT }\end{array}$ & \begin{tabular}{l|l|}
37 & \\
38
\end{tabular} & $\frac{16}{17}$ & $\frac{17}{16}$ & $\frac{53}{57}$ & $\frac{16}{15}$ & $\frac{14}{12}$ & $\therefore$ & 0.017 & $\begin{array}{ll}0.062 \\
0.062\end{array}$ & $\frac{\mathrm{CI}}{\mathrm{CI}}$ & & & & & & \\
\hline
\end{tabular}

(b)

Figure 3. Bore-log data at the location of (a) 1273/1 and (b) 1274/1 (modified after Ghosh and Chandra (2016) [17]). 


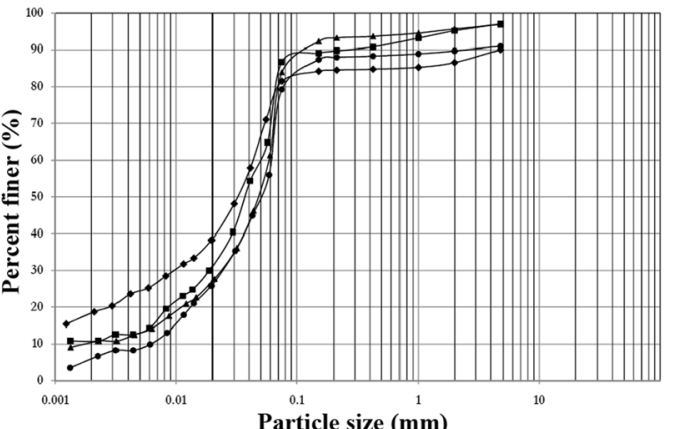

(a)

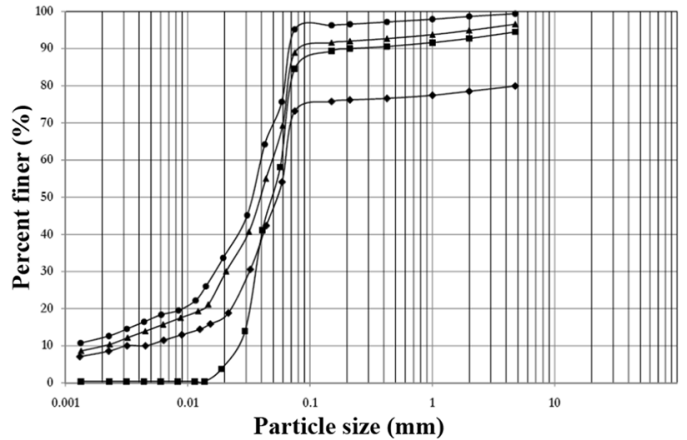

(c)

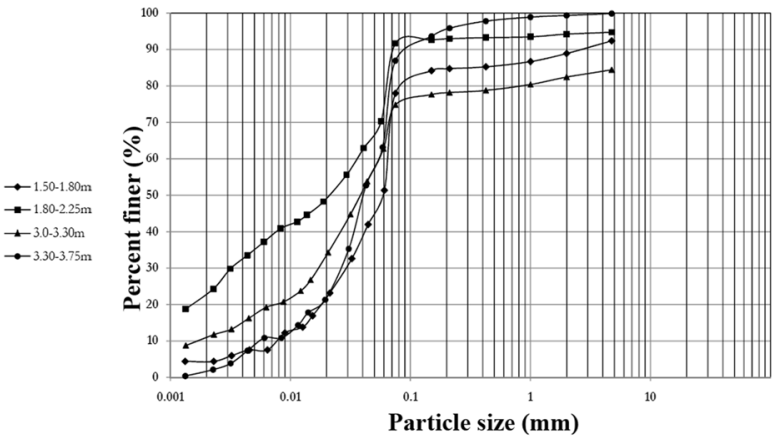

(b)
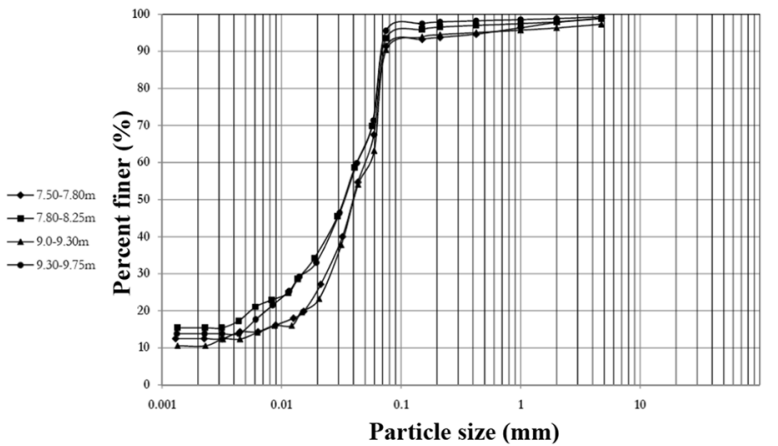

- $-10.50-10.80 \mathrm{~m}$

$-10.80-11.25 \mathrm{~m}$

$\rightarrow-120.1230 \mathrm{~m}$

Figure 4. Typical gradation curves for different depths at the location of 1273/1 (modified after Ghosh and Chandra (2016) [17]).

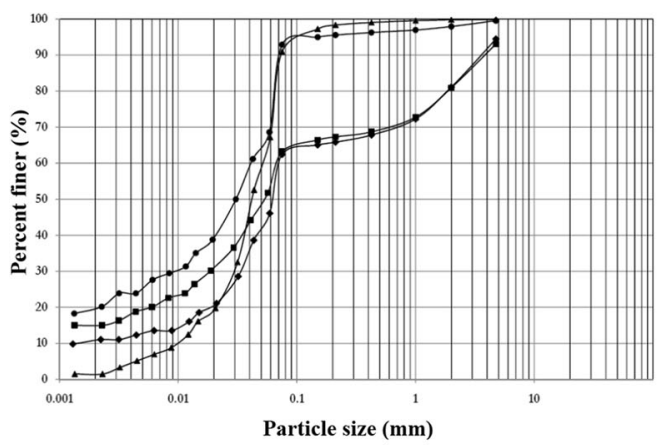

(a)

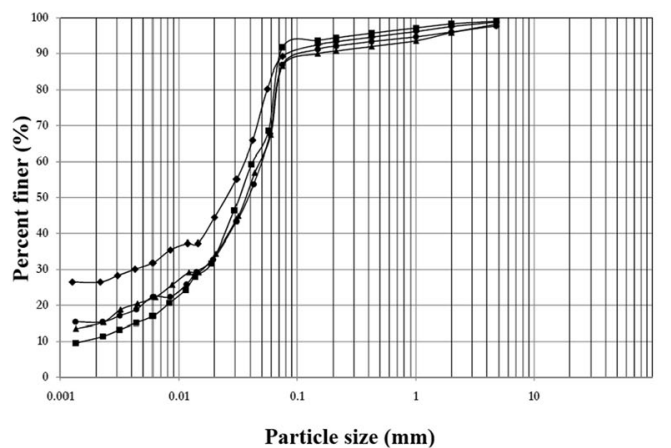

(c)

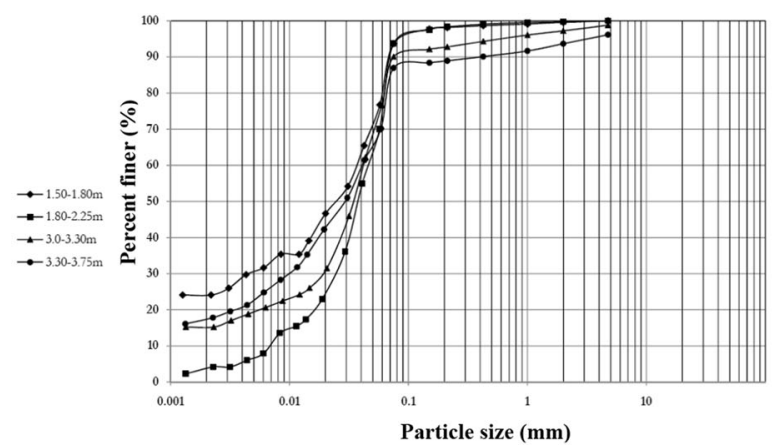

(b)
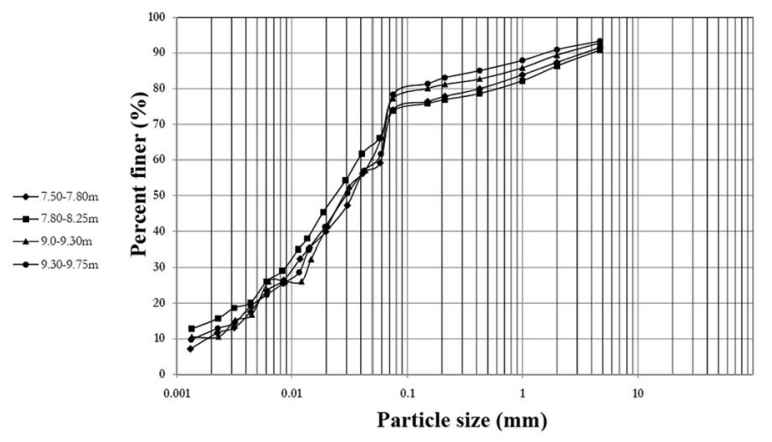

- $10.50-10.80 \mathrm{~m}$
$-10.80-11.25 \mathrm{~m}$

$-12.30-12.75 \mathrm{~m}$

$-4.80-5.25 \mathrm{~m}$

$+6.0-6.30 \mathrm{~m}$

Figure 5. Typical gradation curves for different depths at the location of 1274/1 (modified after Ghosh and Chandra (2016) [17]). 


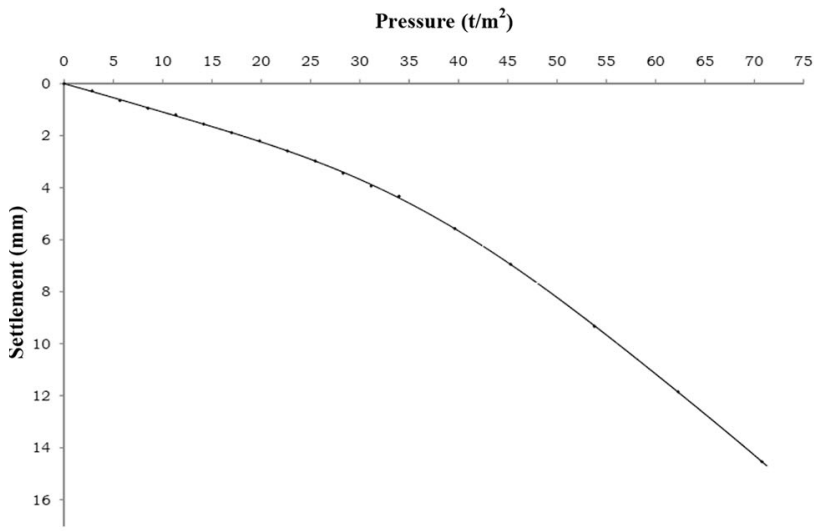

(a)

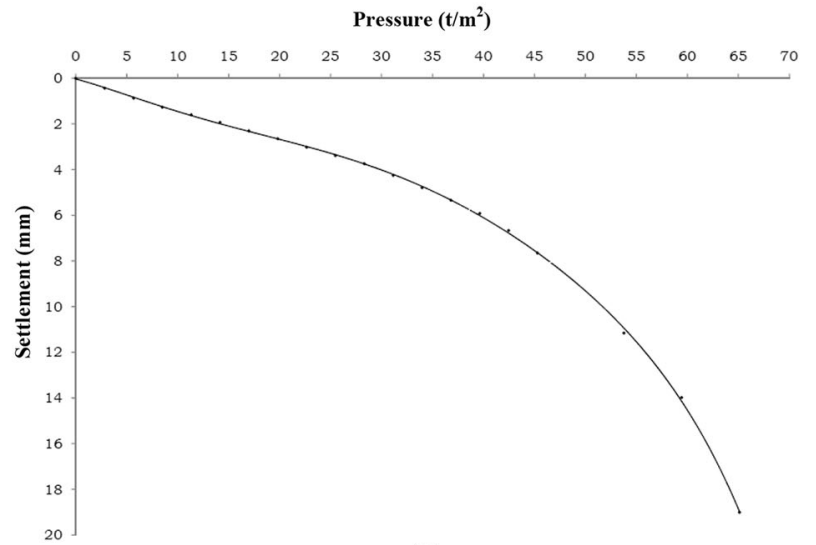

(b)

Figure 6. Pressure-settlement curve from plate load test at the location of (a) 1273/1 and (b) 1274/1 (modified after Ghosh and Chandra (2016) [17]).

ultimate bearing capacity can be determined as $37.5 \mathrm{t} / \mathrm{m}^{2}$ $(367.75 \mathrm{kPa})$. The moisture content of the soil below the test plate was estimated as $15.54 \%$ on the day of conducting the plate load test. Similarly, from the pressure-settlement plot obtained at the location of bridge 1274/1 (figure 6b), it can be noted that the curve follows a conventional and steady-state increasing trend when the pressure on the test plate reaches up to $65.11 \mathrm{t} / \mathrm{m}^{2}(638.51 \mathrm{kPa})$ with a total settlement of $19.01 \mathrm{~mm}$. Considering the double tangent method, the ultimate bearing capacity can be obtained as $51 \mathrm{t} / \mathrm{m}^{2}(500.14 \mathrm{kPa})$. The moisture content of the soil below the test plate was estimated as $16.12 \%$ on the day of conducting the plate load test. Based on the information provided by the Rail Vikas Nigam Limited (RVNL), Kanpur, India, the design load intensity was considered as $15 \mathrm{t} / \mathrm{m}^{2}(147.1 \mathrm{kPa})$. From the pressure-settlement curves obtained from the plate load test performed at different bridge locations, the net safe bearing capacity was found to be more than $147.1 \mathrm{kPa}$, considering a factor of safety equal to 2.5. Hence, keeping the design load intensity $(147.1 \mathrm{kPa})$ in consideration, both locations were found to be safe as far as the plate load test was concerned.

\section{Materials}

The existing bridges consist of super- and sub-structure made of brick masonry. The different strength properties of the foundation soil for bridges $1273 / 1$ and 1274/1 have been extracted from the bore-log data given in figure 3 and are reported in tables 1 and 2, respectively. The bridges carry a layered earth embankment throughout, whose properties are provided by the RVNL. The details of the embankment for both the existing and the proposed bridges are shown in figure 7. The embankment generally consists of three layers, i.e., blanket, SQ2 and SQ1 as shown in figure 7. The depth of different layers (blanket, SQ2 and SQ1) of the embankment was provided by the RVNL. It has been reported by several investigators that the performance of the railway track is highly dependent on the different components such as rails, ballasts and sleepers $[19,20]$. The material properties of the different components of the existing bridge, the track and the embankment are given in tables 3 and 4 for bridges 1273/1 and 1274/1, respectively, whereas the soil properties are determined using the empirical correlations recommended by Das [21]. The elastic modulus of the different layers (blanket, SQ2 and SQ1) of the embankment is determined using the following expression:

$$
E=\beta S_{\mathrm{u}}
$$

where $S_{\mathrm{u}}$ is the undrained shear strength of the soil. The magnitude of the coefficient $\beta$ has been determined from the chart proposed by Das [21]. The different values of $\beta$ for the blanket, SQ2 and SQ1 are found to be 1175, 1125 and 570, respectively.

The Poisson's ratio (v) for the soil has been determined using the following expression [22, 23]:

$$
v=\begin{gathered}
0.25+0.00225(\mathrm{PI}): \text { for clayey soil } \\
0.1+0.3\left(\frac{\phi_{\mathrm{d}}-25}{45^{0}-25^{0}}\right): \text { for granular soil }
\end{gathered}
$$

where $\phi_{\mathrm{d}}$ is the drained angle of internal friction of the soil.

\section{FE modelling}

A schematic diagram of the existing bridges with dimensions is shown in figure 2, as furnished by the RVNL. The length of the existing old bridge $1273 / 1$ is $30.15 \mathrm{~m}$ and that of the newly proposed bridge is $13.291 \mathrm{~m}$; thus the total length of the bridge becomes $43.441 \mathrm{~m}$. The length of the existing old bridge $1274 / 1$ is $37 \mathrm{~m}$, and that of the newly proposed bridge is $18.757 \mathrm{~m}$; thus the total length of the bridge becomes $55.757 \mathrm{~m}$. The FE analysis of the bridge as well as the soil system has been performed using a commercially available FE software ABAQUS/CAE 6.13-4. Eight noded linear brick elements with reduced integration (C3D8R) have been adopted to model the bridge and the soil system since a good mesh of hexahedral elements 
Table 1. Strength properties of soil at the location of bridge 1273/1.

\begin{tabular}{lccccccccc}
\hline $\begin{array}{l}\text { Layer } \\
\text { no. }\end{array}$ & $\begin{array}{c}\text { Depth } \\
(\mathrm{m})\end{array}$ & $\begin{array}{c}\text { Unit weight }(\mathrm{kN} / \\
\left.\mathrm{m}^{3}\right)\end{array}$ & $\begin{array}{c}c_{\mathrm{u}}(\mathrm{kN} / \\
\left.\mathrm{m}^{2}\right)\end{array}$ & $\begin{array}{c}\phi_{\mathrm{u}} \\
(\mathrm{deg})\end{array}$ & $\begin{array}{c}\text { Stress } \\
(\mathrm{kPa})\end{array}$ & $\begin{array}{c}S_{\mathrm{u}} \\
(\mathrm{kPa})\end{array}$ & $\begin{array}{c}\text { Elastic modulus } \\
(\mathrm{MPa})\end{array}$ & $\begin{array}{c}\text { Poisson's ratio } \\
(\mathrm{v})\end{array}$ \\
\hline 1 & 3.00 & 15.11 & 58.84 & 8.5 & 22.66 & 62.23 & 59.74 & 18 & 0.29 \\
2 & 4.50 & 14.62 & 17.65 & 22 & 56.28 & 40.39 & 50.89 & 8 & 0.27 \\
3 & 6.00 & 14.62 & 56.88 & 20 & 78.21 & 85.34 & 74.25 & 21 & 0.30 \\
4 & 7.50 & 15.40 & 25.50 & 5.2 & 100.72 & 34.66 & 35.36 & 16 \\
5 & 9.00 & 16.78 & 35.30 & 10 & 124.86 & 57.32 & 68.78 & 10 & 0.29 \\
6 & 10.50 & 17.07 & 50.99 & 8 & 150.24 & 72.11 & 58.41 & 23 & 0.30 \\
7 & 12.00 & 20.21 & 68.65 & 4 & 178.20 & 81.11 & 80.30 & 17 & 0.29 \\
8 & 13.50 & 20.99 & 32.36 & 4 & 209.10 & 46.98 & 47.92 & 16 & 0.29 \\
\hline
\end{tabular}

Table 2. Strength properties of soil at the location of bridge 1274/1.

\begin{tabular}{lccccccccc}
\hline $\begin{array}{l}\text { Layer } \\
\text { no. }\end{array}$ & $\begin{array}{c}\text { Depth } \\
(\mathrm{m})\end{array}$ & $\begin{array}{c}\text { Unit weight } \\
\left.\mathrm{m}^{3}\right)\end{array}$ & $\begin{array}{c}c_{\mathrm{u}}(\mathrm{kN} / \\
\left.\mathrm{m}^{2}\right)\end{array}$ & $\begin{array}{c}\phi_{\mathrm{u}} \\
(\mathrm{deg})\end{array}$ & $\begin{array}{c}\text { Stress } \\
(\mathrm{kPa})\end{array}$ & $\begin{array}{c}S_{\mathrm{u}} \\
(\mathrm{kPa})\end{array}$ & $\begin{array}{c}\text { Elastic modulus } \\
(\mathrm{MPa})\end{array}$ & $\begin{array}{c}\text { Poisson's ratio } \\
(\mathrm{v})\end{array}$ \\
\hline 1 & 3.00 & 17.66 & 72.57 & 11 & 26.49 & 77.72 & 76.94 & 17 \\
2 & 4.50 & 15.99 & 48.05 & 23 & 64.97 & 75.63 & 74.87 & 17 \\
3 & 6.00 & 19.33 & 21.57 & 0 & 91.45 & 21.57 & 22.65 & 15 \\
4 & 7.50 & 18.74 & 180.44 & 5 & 120.00 & 191.79 & 178.36 & 19 \\
5 & 9.00 & 20.31 & 0.00 & 22 & 149.28 & 60.31 & 61.52 & 16 \\
6 & 10.50 & 19.52 & 62.76 & 7 & 179.16 & 84.76 & 83.91 & 17 \\
7 & 12.00 & Disturbed sample was obtained and hence the properties are considered same as those of layer no. 6. & 0.29 \\
8 & 13.50 & 19.82 & 61.78 & 16 & 237.94 & 130.01 & 124.81 & 18 \\
\hline
\end{tabular}

(C3D8R) usually provides a solution of equivalent accuracy at less cost. The details of the FE meshing for the existing bridge are given in figure 8 . The foundation of the bridges is assumed to rest on the soil surface. The interface between the soil and the foundation is considered as perfectly rough. After performing a sensitivity analysis, the dimensions of the soil domain for bridges 1273/1 and 1274/1 have been chosen as $80 \mathrm{~m} \times 55 \mathrm{~m}$ and $80 \mathrm{~m} \times 50 \mathrm{~m}$ along the $x$ and $z$ directions, respectively (figure 8 ). The depth of the soil deposit along the $y$ direction is kept fixed at $13.5 \mathrm{~m}$. The base of the soil is kept fixed in all three directions, and the sides of the soil domain are allowed to move only in the vertical direction using the roller support. However, for the embankment, only the sides along the $x-y$ plane are restrained with the roller support to move only in the vertical direction. In the analysis, the embankment is considered to behave as linearly elastic. The stress-strain behaviour of the soil in the current analysis is satisfactorily assumed to be linearly elastic.

A 3D FE model developed for the newly proposed bridge along with the existing bridge is shown in figure 9 . The boundary conditions are kept similar to those of the model developed for the existing bridge. For bridges $1273 / 1$ and 1274/1, the length of the soil domain is kept as 90 and $100 \mathrm{~m}$, respectively, to accommodate the extension due to the proposed structure. However, the width and the depth of the domain are kept same as those of the model developed for the existing bridge. The discretization of the ballast, the track and the soil has been carried out using C3D8R elements, whereas the embankment has been discretized using C3D4 elements available in ABAQUS. It is worth noting that C3D4 is a general purpose tetrahedral element with four nodes and one integration point. As the embankment continues along the $z$ direction on either side of the bridge, an equivalent surcharge is considered at the ground level for both the existing as well as the proposed bridge.

\section{Train loading}

The span between Kanpur Central and Parichha $\left(25.5188^{\circ} \mathrm{N}, 78.7383^{\circ} \mathrm{E}\right)$, near Jhansi Junction, is designated as the feeder route of the dedicated freight corridor (DFC) by the IR on which heavy axle trains are expected to travel for feeding coal to the Parichha Thermal Power Station. Hence, in the present analysis, the train loading has been considered as DFC $32.5 \mathrm{t}$ for all the tracks as reported by Chakrabarti [24], which has been recommended by the IR for the dedicated freight corridor. Detailed discussion on 


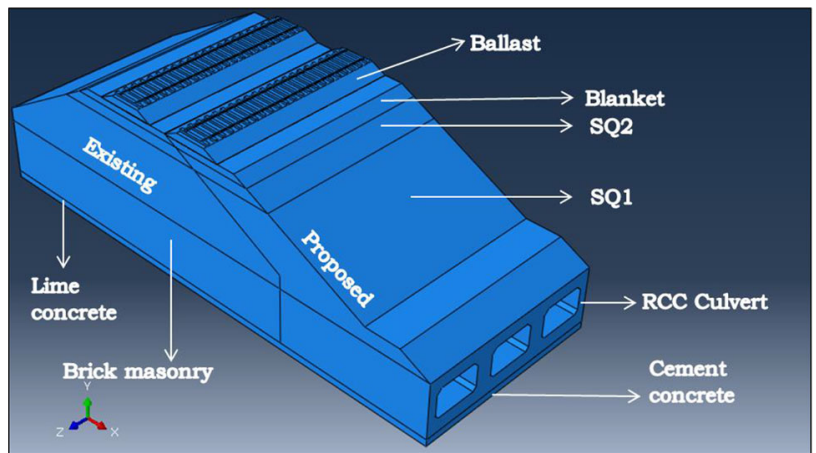

(a)

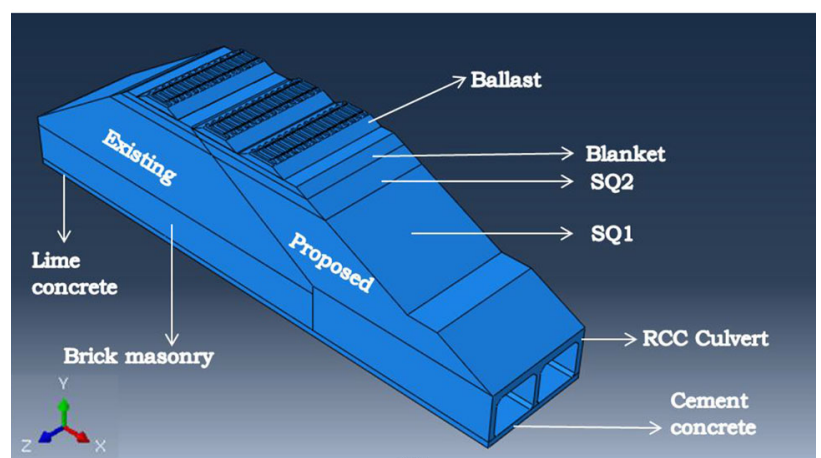

(b)

Figure 7. Details of the embankment for (a) 1273/1 and (b) $1274 / 1$.

Table 3. Material properties of different components of bridge, track and embankment for bridge 1273/1.

\begin{tabular}{lccc}
\hline & \multicolumn{3}{c}{ Properties } \\
\cline { 2 - 4 } Material & $\begin{array}{c}\text { Density }(\mathrm{kg} / \\
\left.\mathrm{m}^{3}\right)\end{array}$ & $\begin{array}{c}\text { Elastic modulus } \\
(\mathrm{MPa})\end{array}$ & $\begin{array}{c}\text { Poisson's } \\
\text { ratio }\end{array}$ \\
\hline Brick masonry & 1700 & 2500 & 0.2 \\
Ballast & 1800 & 30.49 & 0.15 \\
Blanket & 1960 & 13.22 & 0.15 \\
SQ2 & 1860 & 27.91 & 0.32 \\
SQ1 & 1810 & 39.11 & 0.295 \\
Lime/cement & 2400 & $2.5 \times 10^{4}$ & 0.2 \\
$\quad$ concrete & 7477 & $2.1 \times 10^{5}$ & 0.3 \\
Steel rail & 2756 & $3.845 \times 10^{4}$ & 0.2 \\
Sleeper & & & \\
\hline
\end{tabular}

the DFC loading is not repeated in this paper, for which the report of Chakrabarti [24] can be referred. However, the details of the DFC $32.5 \mathrm{t}$ loading are schematically shown in figure 10, where the axel loadings as well as the distance between the axle loadings for both diesel loco and wagons are clearly demonstrated. The rail loads are applied as quasi-static point loads on the existing as well as the newly proposed tracks. The applied axle loads have been made double considering the dynamic factor.
Table 4. Material properties of different components of bridge, track and embankment for bridge 1274/1.

\begin{tabular}{lccc}
\hline & \multicolumn{3}{c}{ Properties } \\
\cline { 2 - 4 } Material & $\begin{array}{c}\text { Density }(\mathrm{kg} / \\
\left.\mathrm{m}^{3}\right)\end{array}$ & $\begin{array}{c}\text { Elastic modulus } \\
(\mathrm{MPa})\end{array}$ & $\begin{array}{c}\text { Poisson's } \\
\text { ratio }\end{array}$ \\
\hline Brick masonry & 1700 & 2500 & 0.2 \\
Ballast & 1800 & 30.49 & 0.15 \\
Blanket & 1960 & 13.22 & 0.15 \\
SQ2 & 1860 & 27.91 & 0.32 \\
SQ1 & 1810 & 85.81 & 0.295 \\
Lime/cement & 2400 & $2.5 \times 10^{4}$ & 0.2 \\
$\quad$ concrete & 7477 & $2.1 \times 10^{5}$ & 0.3 \\
Steel rail & 2756 & $3.845 \times 10^{4}$ & 0.2 \\
Sleeper & & & \\
\hline
\end{tabular}

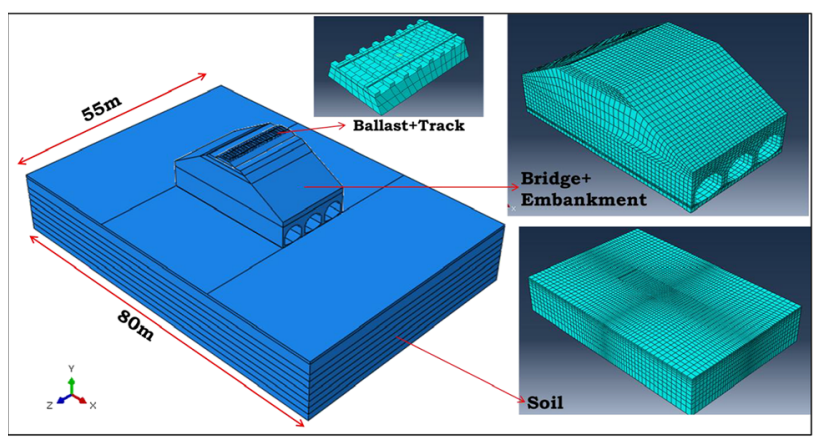

(a)

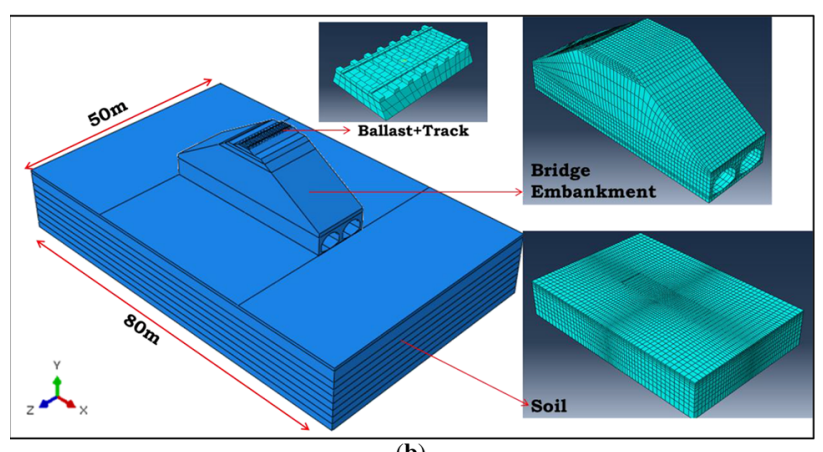

(b)

Figure 8. 3D FE model and discretization of the existing bridge: (a) $1273 / 1$ and (b) $1274 / 1$.

\section{Results and discussion}

The computation time needed for the whole analysis typically ranges from 9 to 14 min depending upon the number of elements present in the model. For bridge 1273/1, three typical sections have been selected for determining the vertical stress and the settlement distribution developed below the foundation (figure 11a). Section-AA represents the section along the centreline of the existing track. Section-BB represents the edge (end) of the existing bridge, i.e., the junction between the existing and the proposed 

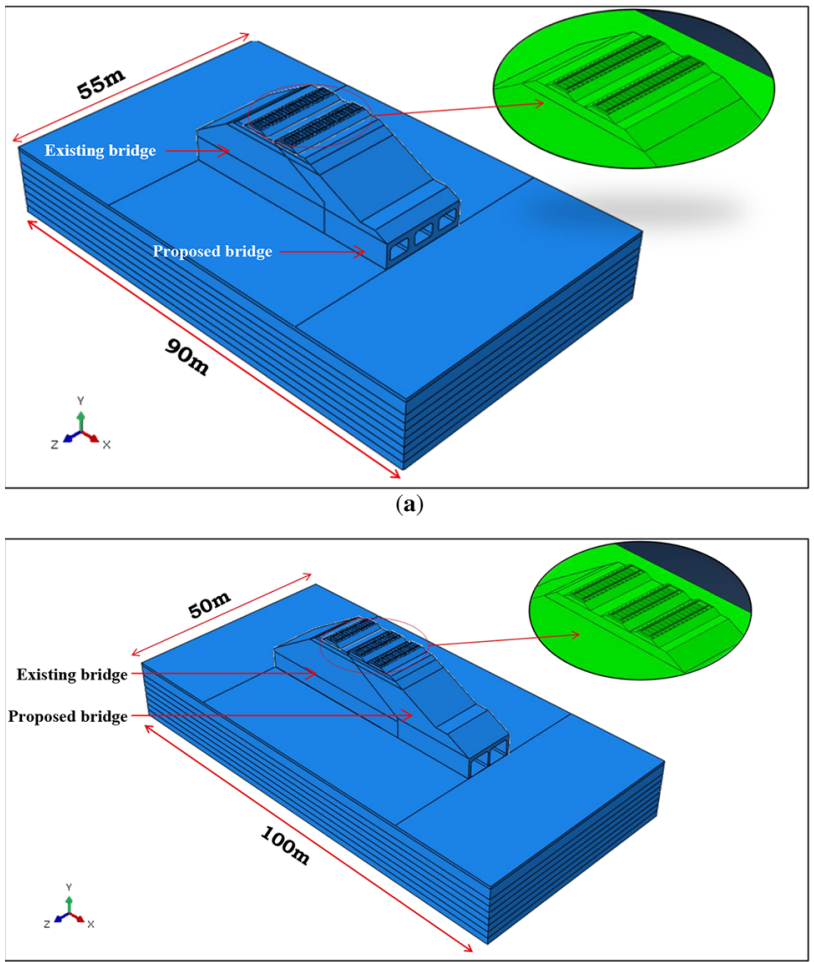

(b)

Figure 9. 3D FE model of the proposed bridge along with the existing bridge: (a) 1273/1 and (b) 1274/1.

bridge. Section-CC represents the section along the centreline of the proposed track as shown in figure 11a. Similarly, for bridge 1274/1, four typical sections have been selected for obtaining the vertical stress and the settlement
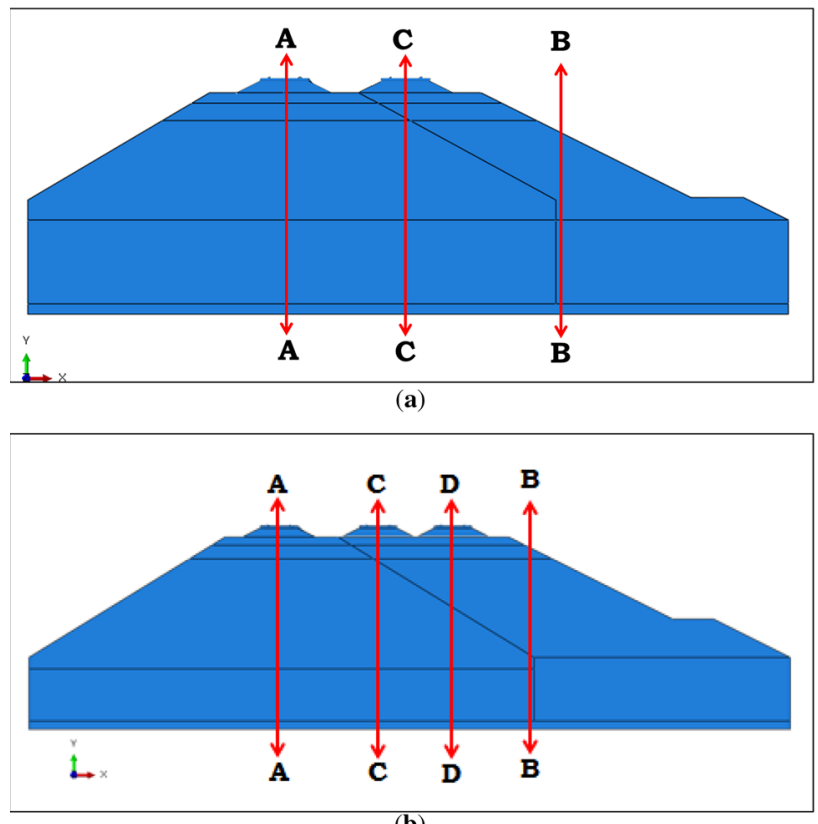

(b)

Figure 11. Selected sections to determine vertical stress and settlement for (a) 1273/1 and (b) 1274/1.

distribution developed below the foundation (figure 11b). Section-AA represents the section along the centreline of the existing track. Section-BB represents the edge (end) of the existing bridge, i.e. the junction between the existing and the proposed bridge. Section-CC and section-DD represent the sections along the centreline of the two proposed tracks as shown in figure $11 \mathrm{~b}$. The analysis has been

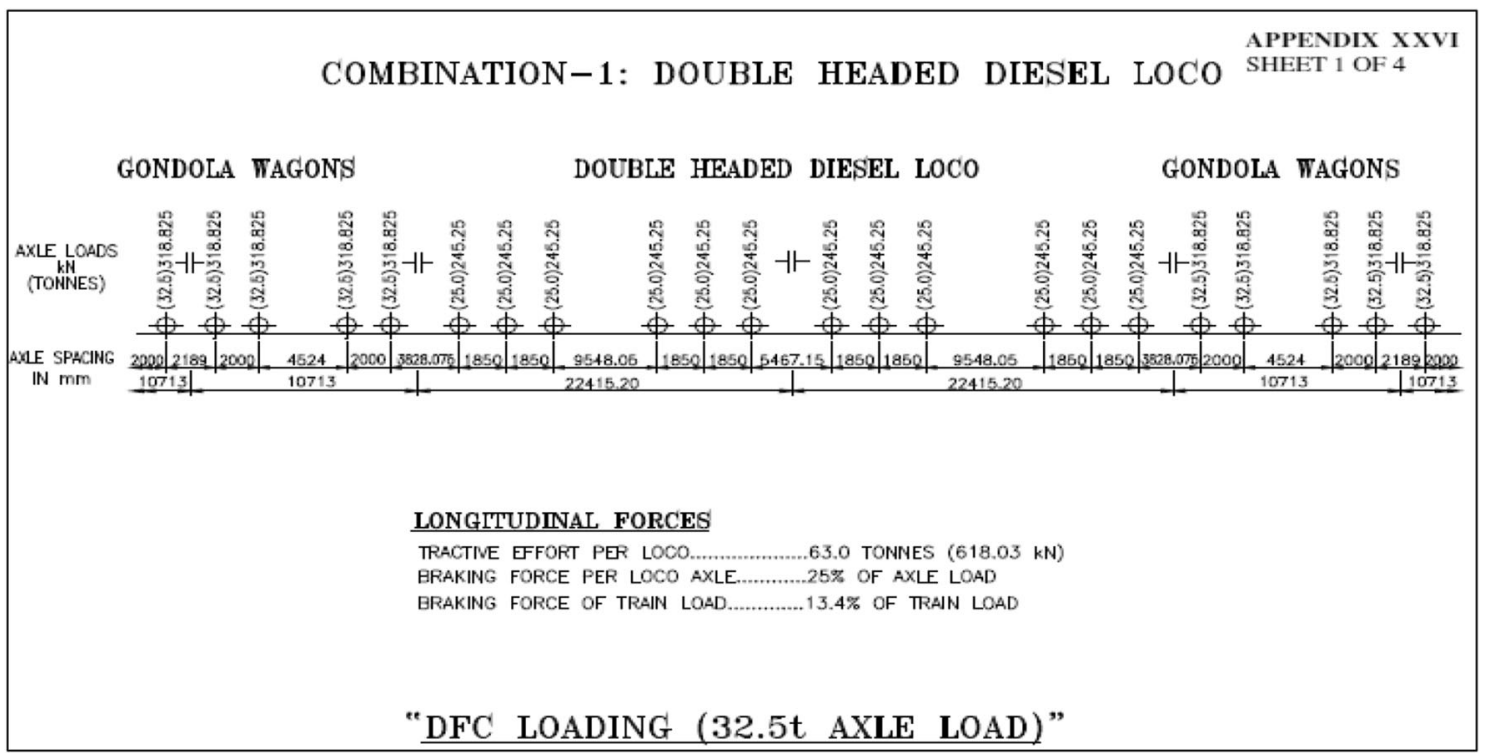

Figure 10. Loading standards for DFC loading (modified after Chakrabarti (2016) [24]). 
Table 5. Maximum vertical stress and settlement at different sections at different loading conditions for bridge $1273 / 1$.

\begin{tabular}{|c|c|c|c|c|c|c|c|}
\hline \multicolumn{2}{|l|}{ Section } & \multicolumn{2}{|c|}{$\mathrm{AA}$} & \multicolumn{2}{|c|}{$\mathrm{BB}$} & \multicolumn{2}{|c|}{$\mathrm{CC}$} \\
\hline Loads & & $\begin{array}{l}\text { Only } \\
\text { DL }\end{array}$ & $\begin{array}{l}\mathrm{DL}+\text { train } \\
\quad \text { load }\end{array}$ & $\begin{array}{l}\text { Only } \\
\text { DL }\end{array}$ & $\begin{array}{l}\mathrm{DL}+\text { train } \\
\quad \text { load }\end{array}$ & $\begin{array}{l}\text { Only } \\
\text { DL }\end{array}$ & $\begin{array}{l}\mathrm{DL}+\text { train } \\
\quad \text { load }\end{array}$ \\
\hline \multirow[t]{2}{*}{ Existing: 1273/1 } & $\begin{array}{c}\text { Maximum vertical stress } \\
\qquad(\mathrm{kPa})\end{array}$ & 180.8 & 201.3 & 120.9 & 129.6 & 172.5 & 189.4 \\
\hline & $\begin{array}{c}\text { Maximum settlement } \\
(\mathrm{mm})\end{array}$ & 26.23 & 29.03 & 21.94 & 23.76 & 25.14 & 27.56 \\
\hline $\begin{array}{l}\text { Proposed: 1273/1 } \\
\text { (considering }\end{array}$ & $\begin{array}{c}\text { Maximum vertical stress } \\
\qquad(\mathrm{kPa})\end{array}$ & 188.7 & 219.2 & 154.0 & 168.4 & 190.1 & 219.8 \\
\hline $\begin{array}{l}\text { train load on both } \\
\text { tracks) }\end{array}$ & $\begin{array}{c}\text { Maximum settlement } \\
(\mathrm{mm})\end{array}$ & 27.62 & 32.03 & 25.04 & 27.82 & 27.51 & 31.70 \\
\hline
\end{tabular}

Table 6. Maximum vertical stress and settlement at different sections at different loading conditions for bridge 1274/1.

\begin{tabular}{|c|c|c|c|c|c|c|c|c|c|}
\hline \multicolumn{2}{|l|}{ Section } & \multicolumn{2}{|r|}{ AA } & \multicolumn{2}{|r|}{$\mathrm{BB}$} & \multicolumn{2}{|r|}{$\mathrm{CC}$} & \multicolumn{2}{|r|}{ DD } \\
\hline Loads & & $\begin{array}{l}\text { Only } \\
\text { DL }\end{array}$ & $\begin{array}{c}\mathrm{DL}+\text { train } \\
\text { load }\end{array}$ & $\begin{array}{l}\text { Only } \\
\text { DL }\end{array}$ & $\begin{array}{c}\mathrm{DL}+\text { train } \\
\text { load }\end{array}$ & $\begin{array}{l}\text { Only } \\
\text { DL }\end{array}$ & $\begin{array}{c}\mathrm{DL}+\text { train } \\
\text { load }\end{array}$ & $\begin{array}{l}\text { Only } \\
\text { DL }\end{array}$ & $\begin{array}{c}\mathrm{DL}+\text { train } \\
\text { load }\end{array}$ \\
\hline \multirow[t]{2}{*}{ Existing: 1274/1 } & $\begin{array}{l}\text { Maximum } \\
\text { vertical } \\
\text { stress } \\
(\mathrm{kPa})\end{array}$ & 217.4 & 241.9 & 141.5 & 149.9 & 198.8 & 217.4 & 172.6 & 185.5 \\
\hline & $\begin{array}{l}\text { Maximum } \\
\text { settlement } \\
(\mathrm{mm})\end{array}$ & 25.59 & 28.34 & 17.85 & 19.08 & 24.28 & 26.58 & 21.52 & 23.22 \\
\hline \multirow[t]{2}{*}{$\begin{array}{l}\text { Proposed: } 1274 / 1 \\
\text { (considering train load } \\
\text { on both tracks) }\end{array}$} & $\begin{array}{c}\text { Maximum } \\
\text { vertical } \\
\text { stress } \\
(\mathrm{kPa})\end{array}$ & 239.3 & 288.8 & 171.3 & 197.3 & 261.5 & 322.8 & 233.7 & 281.7 \\
\hline & $\begin{array}{l}\text { Maximum } \\
\text { settlement } \\
(\mathrm{mm})\end{array}$ & 27.88 & 33.57 & 25.25 & 29.14 & 28.58 & 34.92 & 27.07 & 32.54 \\
\hline
\end{tabular}

performed in two different stages. In the first stage, the structure has been analysed considering only the dead load (DL), whereas in the second stage, the train load (live load) has been applied on the track. The magnitude of the maximum vertical stress and the settlement developed below the foundation at the selected sections is tabulated in tables 5 and 6 for bridges 1273/1 and 1274/1, respectively. In this case study, the occurrence of interaction between the foundations of existing and proposed bridge is quite obvious due to close spacing. For bridge 1273/1, the maximum vertical stress at section-AA is observed to increase from 201.3 to $219.2 \mathrm{kPa}$, resulting in about $8.93 \%$ increase due to the placement of the proposed railway track. Section-BB is found to be critical as it serves as the junction between the existing and the proposed bridges. The analysis shows an increase in the maximum vertical stress from 129.6 to $168.4 \mathrm{kPa}$ at section-BB, i.e. $29.91 \%$ increase due to the placement of the proposed railway track. Similarly, the maximum settlement at section-AA and section-BB is observed to increase from 29.03 to 32.03 and from 23.76 to
$27.82 \mathrm{~mm}$, respectively, resulting in about $10.33 \%$ and $17.09 \%$ increase due to the placement of the proposed railway track. The maximum vertical stress and the settlement at section-CC is found to increase from 189.4 to $219.8 \mathrm{kPa}$ and from 27.56 to $31.7 \mathrm{~mm}$, respectively, resulting in about $16.07 \%$ and $15.02 \%$ increase due to the placement of the proposed railway track. After placement of the proposed bridge, among all the three sections (AA, $\mathrm{BB}$ and $\mathrm{CC}$ ), the maximum difference in the settlement between only DL condition and DL plus train load condition is found to be $6.56 \mathrm{~mm}(31.7-25.14 \mathrm{~mm}=6.56 \mathrm{~mm})$, which occurs at section-CC. This value is well within the permissible settlement limit of $25 \mathrm{~mm}$, as per the IR Standard code (IR Standard 2013). On the contrary, for bridge 1274/1, the maximum vertical stress at section-AA is observed to increase from 241.9 to $288.8 \mathrm{kPa}$, resulting in about $19.38 \%$ increase due to the placement of the proposed railway track. Section-BB is found to be critical as it serves as the junction between the existing and the proposed bridges. The analysis shows an increase in the 


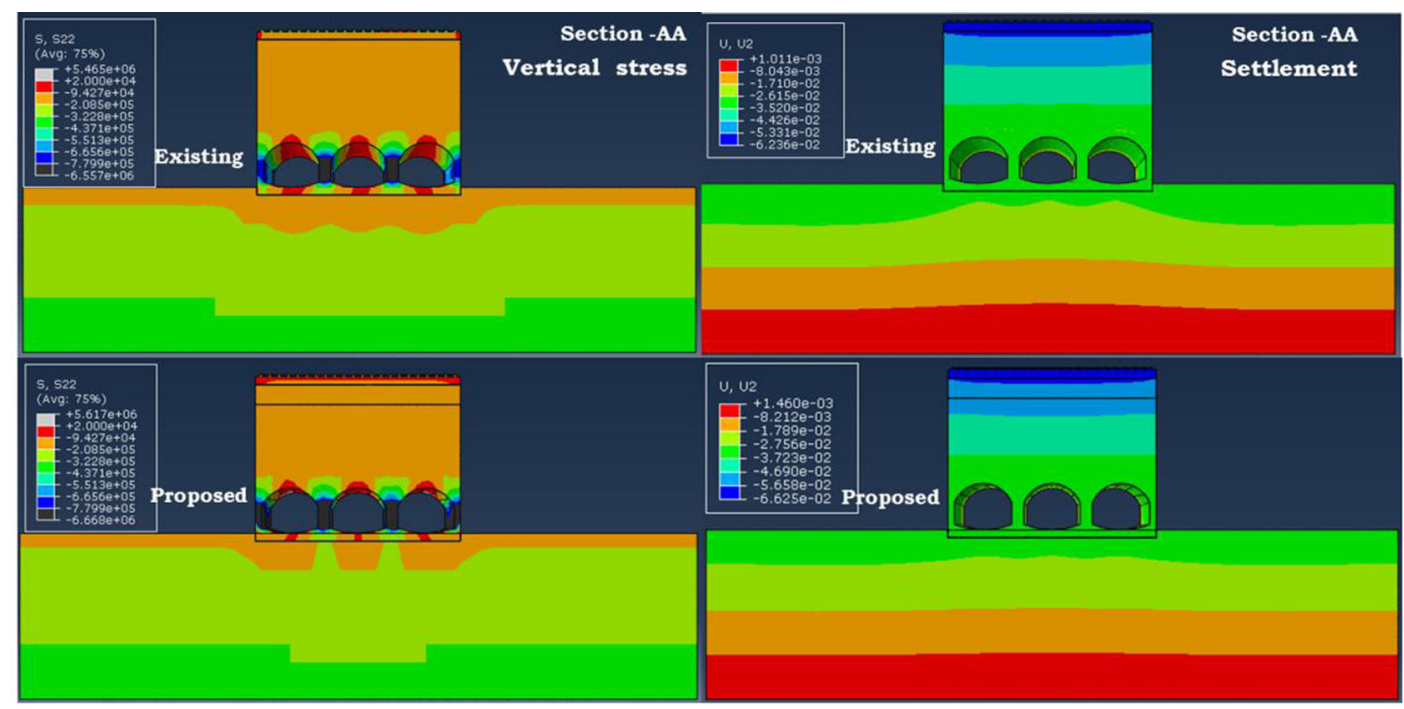

(a)

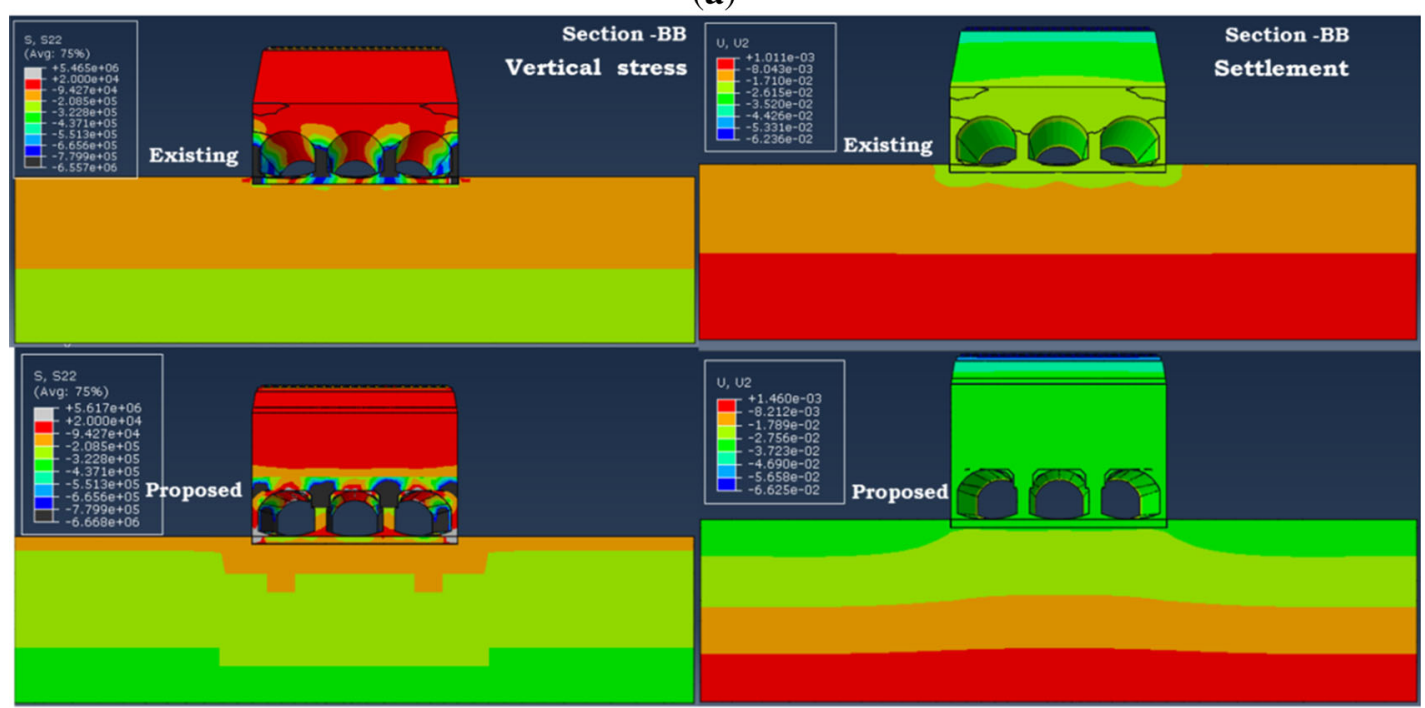

(b)

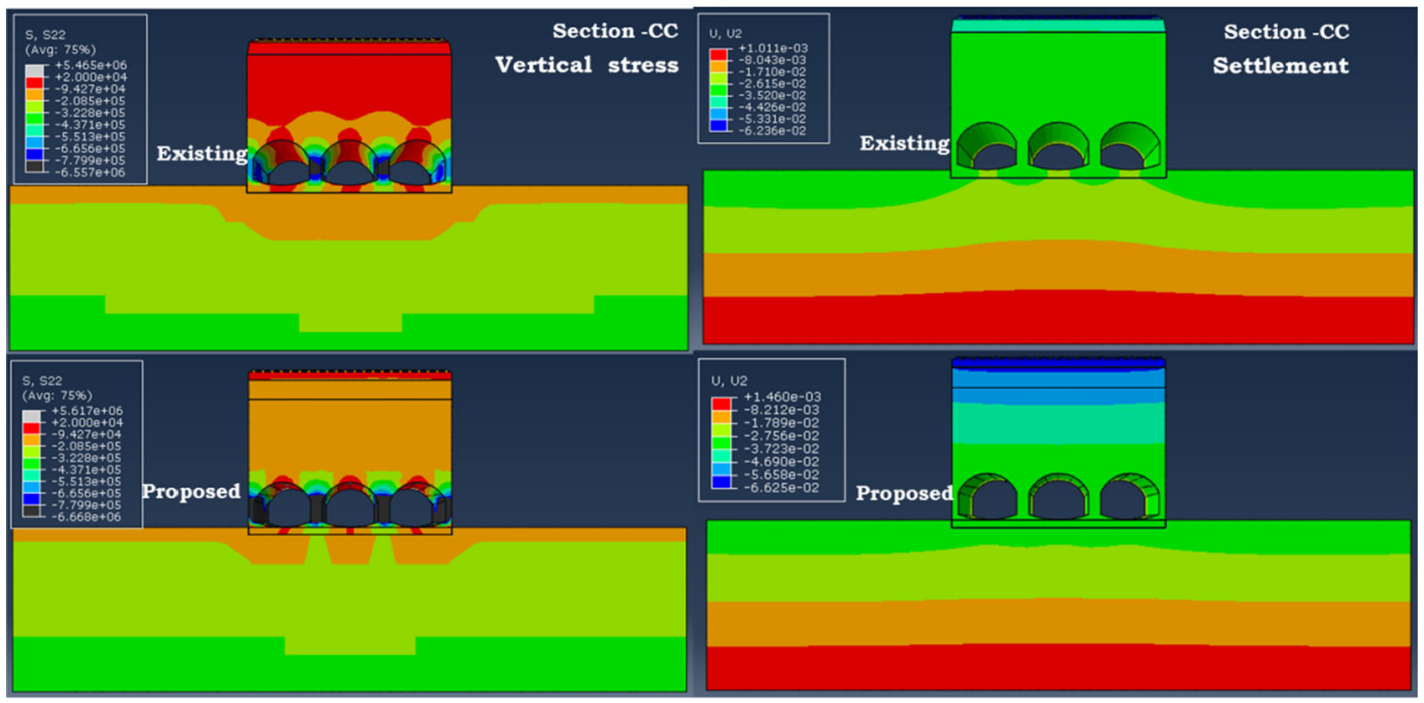

(c)

Figure 12. Vertical stress and settlement distribution for $1273 / 1$ at section (a) AA, (b) BB and (c) CC. 


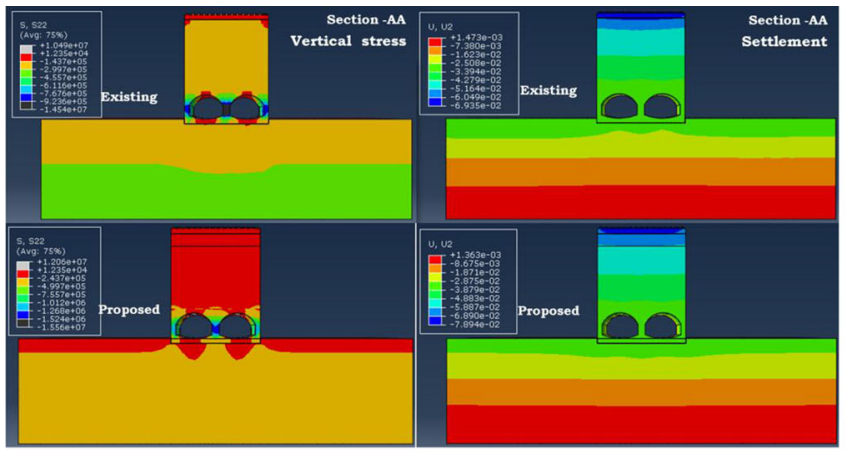

(a)

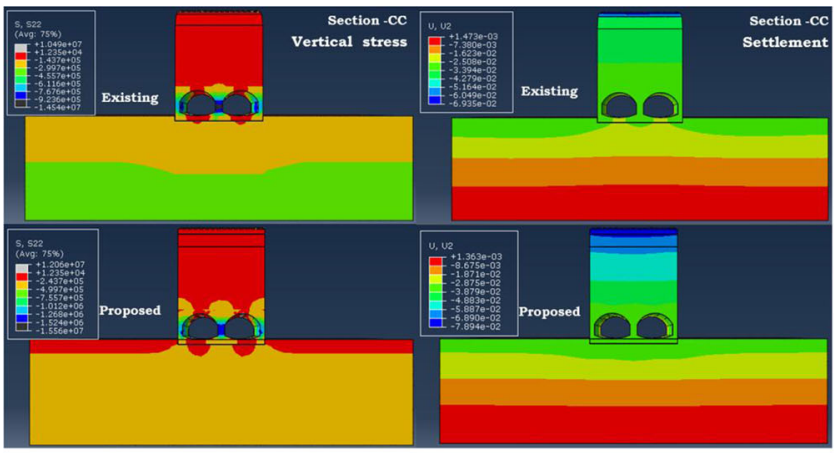

(c)

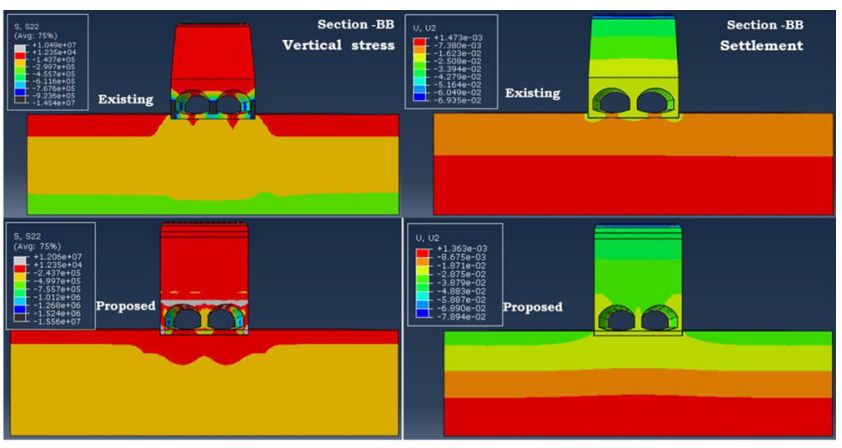

(b)

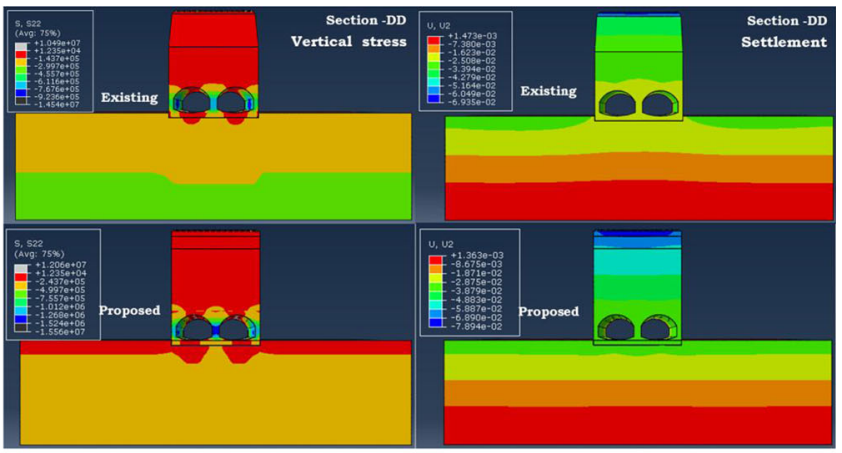

(d)

Figure 13. Vertical stress and settlement distribution for $1274 / 1$ at section (a) AA, (b) BB, (c) CC and (d) DD.

maximum vertical stress from 149.9 to $197.3 \mathrm{kPa}$ at section-BB, i.e., $31.64 \%$ increase due to the placement of the proposed railway track. Similarly, the maximum settlement at section-AA and section-BB is observed to increase from 28.34 to 33.57 and from 19.08 to $29.14 \mathrm{~mm}$, respectively, resulting in about $18.45 \%$ and $52.72 \%$ increase due to the placement of the proposed railway track. The maximum vertical stress and the settlement at section-CC are found to increase from 217.4 to $322.8 \mathrm{kPa}$ and from 26.58 to $34.92 \mathrm{~mm}$, respectively, resulting in about $48.5 \%$ and $31.37 \%$ increase due to the placement of the proposed railway track. Similarly, the maximum vertical stress and the settlement at section-DD is found to increase from 185.5 to $281.7 \mathrm{kPa}$ and from 23.22 to $32.54 \mathrm{~mm}$, respectively, resulting in about $51.88 \%$ and $40.14 \%$ increase due to the placement of the proposed railway track. After placement of the proposed bridge, among all the four sections (AA, BB, CC and DD), the maximum difference in the settlement between only DL condition and DL plus train load condition is found to be $11.29 \mathrm{~mm}$ $(29.14-17.85 \mathrm{~mm}=11.29 \mathrm{~mm})$, which occurs at sectionBB. This value is well within the permissible settlement limit of $25 \mathrm{~mm}$, as per the IR Standard code [25].

Under the combined effect of the DL and the train load, the contour plots of the vertical stress and the settlement distribution at different sections of bridges 1273/1 and $1274 / 1$ in the presence of the existing as well as the proposed structure are shown in figures 12 and 13, respectively. It can be observed from the contour plots depicted in figures 12 and 13 that the vertical stress and the settlement developed below the foundation of the existing bridge get significantly enhanced by the placement of the proposed bridge.

\section{Conclusions}

In the present study, the geotechnical stability of the substructure of more than 100-year-old brick masonry arch bridges has been analysed numerically due to the construction of the adjacent newly proposed concrete box bridges. Two different bridges (1273/1 and 1274/1) have been considered in this analysis. Bridge $1273 / 1$ is made of brick masonry with three barrels, whereas bridge $1274 / 1$ is made of brick masonry with two barrels. For bridges $1273 / 1$ and $1274 / 1$, the maximum vertical stress developed at the base of the foundation of the existing bridge in the presence of the proposed bridge is found to be 219.83 and $322.83 \mathrm{kPa}$, respectively, which is significantly lower than the ultimate bearing capacity (367.75 and $500.14 \mathrm{kPa}$, respectively) obtained at the respective bridge locations. After placement of the proposed bridge, among all the selected sections, the maximum difference in the settlement between only DL condition and DL plus train load condition is found to be 
6.56 and $11.29 \mathrm{~mm}$ for bridges 1273/1 and 1274/1, respectively, which is well within the permissible settlement limit of $25 \mathrm{~mm}$. Hence, both of the existing bridges may be considered to be safe with respect to the strength and the serviceability criteria of the foundation.

\section{Acknowledgements}

The authors are thankful for the financial support provided by the Rail Vikas Nigam Limited (RVNL), Kanpur, India, to carry out the present work through a sponsored project [Ref No. 42/CPM/RVNL/CNB/2015/ 44].

\section{References}

[1] Bowles J E 1977 Foundation analysis and design. New York, USA: McGraw-Hill

[2] Das B M and Larbi-Cherif S 1983 Bearing capacity of two closely-spaced shallow foundations on sand. Soils and Foundations 23(1): 1-7

[3] Das B M, Puri V K and Neo B K 1993 Interference effects between two surface footings on layered soil. Transportation Research Record 1406, Transportation Research Board, Washington, DC, pp. 34-40

[4] Ghosh P and Kumar S R 2011 Interference effect of two nearby strip surface footings on cohesionless layered soil. International Journal of Geotechnical Engineering 5(1): 87-94

[5] Griffiths D V, Fenton G A and Manoharan N 2006 Undrained bearing capacity of two strip footings on spatially random soil. International Journal of Geomechanics 6(6): 421-427

[6] Kumar J and Bhoi M K 2009 Interference of two closely spaced strip footing on sand using model test. Journal of Geotechnical and Geoenvironmental Engineering 135(4): 595-604

[7] Kumar J and Ghosh P 2007 Ultimate bearing capacity of two interference rough strip footings. International Journal of Geomechanics 7(1): 53-62

[8] Kumar J and Ghosh P 2007 Upper bound limit analysis for finding interference effect of two nearby strip footing on sand. Geotechnical and Geological Engineering 25(5): 499-507

[9] Kumar J and Kouzer K M 2007 Bearing capacity of two interfering footings. International Journal for Numerical Analytical Methods in Geomechanics 32(3): 251-264

[10] Lavasan A A, Ghazavi M, von Blumenthal A and Schanz T 2018 Bearing capacity of interfering strip footings. Journal of Geotechnical and Geoenvironmental Engineering 144(3): 04018003
[11] Saran S and Agarwal V C 1974 Interference of surface footings on sand. Indian Geotechnical Journal 4(2): 129-139

[12] Selvadurai A P S and Rabbaa S A A 1983 Some experimental studies concerning the contact stresses beneath interfering rigid strip foundations resting on a granular stratum. Canadian Geotechnical Journal 20(3): 406-415

[13] Stuart J G 1962 Interference between foundations, with special reference to surface footings in sand. Geotechnique 12(1): 15-22

[14] West J M and Stuart J G 1965 Oblique loading resulting from interference between surface footings on sand. In: Proceedings of the 6th International Conference on Soil Mechanics and Foundation Engineering, Montreal, vol. 2, pp. 214-217

[15] Perloff W H 1975 Pressure distribution and settlement. In: Foundation engineering handbook

[16] IS 2131 - 1981 (reaffirmed 2002) 2002 Method for standard penetration test for soils. 1st Revision, Bureau of Indian Standards, Manak Bhavan, New Delhi, India

[17] Ghosh P and Chandra S 2016 Geotechnical investigations for seven old arch bridges in connection with doubling of tracks between Kanpur and Jhansi. Report No. CE/GTE/PG/2016/ 420, September 29

[18] IS 1888 - 1982 (reaffirmed 2002) 2002 Method of load test on soils. 2nd Revision, Indian Standards Institution, Manak Bhavan, New Delhi, India

[19] Laryea S, Safari Baghsorkhi M, Ferellec J F, McDowell G R and Chen C 2014 Comparison of performance of concrete and steel sleepers using experimental and discrete element methods. Transportation Geotechnics 1: 225-240

[20] Shahraki M, Warnakulasooriya C and Witt K J 2015 Numerical study of transition zone between ballasted and ballastless railway track. Transportation Geotechnics 3: 58-67

[21] Das B M 1997 Advanced soil mechanics. London, UK: Taylor and Francis

[22] Trautmann C H and Kulhawy F H 1987 CUFAD-a computer program for compression and uplift foundation analysis and design. Report EL-4540-CCM, 16, Electrical Power and Research Institute

[23] Wroth C P 1975 In situ measurement of initial stresses and deformation characteristics. In: Proceedings of the Specialty Conference on In Situ Measurement of Soil Properties, vol. 2, pp. 180-230

[24] Chakrabarti S K 2016 Evaluation of structural adequacy of bridge no. 1130/2 and its strengthening for the doubling of track between Kanpur and Jhansi (structural-scope only), Kanpur

[25] Indian Railway Standard (IRS) 2013 Code of practice for the design of sub-structures and foundations of bridges. 2nd Revision, Research Designs and Standards Organisation, Lucknow, India 